\title{
Panarchy, ontological and epistemological phenomena, and the Plague
}

\author{
$\underline{\text { Sean Geobev }}^{1}$ and Katharine A. McGowan ${ }^{2}$
}

\begin{abstract}
Building resilience to major economic, social, and ecological crises such as armed conflict and natural disasters is seen as critical to maintaining system integrity. Although studies of system survival can be used to gauge whether or not social systems are resilient, this can only be conducted in retrospect. Contemporary measures of resilience rely on proxy measures that one can argue build capacity for resilience, but are not direct proxies for resilience itself, except in highly subscribed conditions. This leads us to our key research questions: Can the resilience of a system be measured contemporaneously by those within a social system? What can we learn from past efforts to understand the resilience of social systems by those living through their transformations?
\end{abstract}

To answer these we examine Europe in the second half of the 14th century, during the outbreak and spread of the Plague through the continent. Through an examination of academic research relying on contemporary accounts during this period, we examine the indicators Europeans used at the time to understand changes in their social-ecological systems. We find a time lag between quantitative indicators of system resilience and the systemic shocks introduced by the Plague. However, narratives from the time suggest that those who experienced the epidemic were trying to develop personal understandings of the social changes around them and collective understandings of how to respond to these crises, both in advance of collecting easily comparable data that could be used for broader administrative purposes. The progression from individual narratives, to common understandings, and finally to comparable data is likely a common process that occurs as those within a social-ecological system make sense of a shift of the system from one arrangement to another.

Key Words: complexity; measurement; narrative; resilience

\section{INTRODUCTION}

In the late 1960s, faced with the real possibility of nuclear war, the RAND Corporation commissioned economist J. Hirshleifer to write a report on the Black Death (1348-1350, hereafter referred to as the Plague), a historical event that "perhaps approaches nuclear war in geographical extent, abruptness of onset, and scale of casualties...[that] may help illuminate some of the sources of, and limitations upon, the human potentialities for recovery from any great catastrophe" (Hirshleifer 1966:iii). In considering this nearly idealized form of external shock to a social system, Hirshleifer decided that Europe ultimately did not undergo social or economic collapse, and instead experienced rapid economic and political recovery in the face of significant population loss, surely a comforting thought for RAND's military partners.

Yet Hirshleifer's conclusions, while strongly supported by thencurrent research, are at odds with many contemporary observers of the Plague's mid-14th century journey through Europe and with a significant proportion of (although not all) historical analysis. Consider DeWitte's (2014a:260) somewhat circular evaluation of the Plague's importance to human history: "This massive, extremely rapid depopulation event initiated or enhanced social, demographic, and economic changes throughout Europe." Bridbury (1973:591), meanwhile, described the population loss as "more purgative than toxic" to European socioeconomic and cultural systems. This ambiguity presents us with a conundrum: Although studies of system survival can be used to gauge a social system's resilience, this can seemingly only be conducted in retrospect, and is often difficult to differentiate among the white noise of historical trends. Can we understand how people make sense of complex systemic change from inside that system in real time?
These questions should inform resilience analysis, and the various fields contingent on a coherent concept of resilience, including social innovation. Building resilience to major economic, social, and ecological crises such as armed conflict and natural disasters is seen as critical to maintaining system integrity (Fath et al. 2015), and yet Gunderson's (2002) warning of normative questions of for whom and of what underline a risk of unconscious conservatism (Cretney 2014). Normativity and deterministic tendencies have been identified as risks in social resilience research (Geels 2010, Cote and Nightingale 2012), and improved theorization has not fully resolved these. We see this tension in Plague historiography as well. The range of variables available, especially across temporal and spatial planes, make it possible to argue both for and against the proposition that Medieval Europe was resilient through the Plague.

\section{Research objectives}

Using the Plague, its voluminous recent historiography, and the extensive history as a set of resources, we seek to understand how people make sense of complex systemic changes from inside those systems in real time. We use this to develop an approach for understanding how people understand changes and systemic resilience from within that system.

\section{Research questions}

- Can the resilience of a system be measured contemporaneously by those within a social system?

- What can we learn from past efforts to understand the resilience of social systems by those living through their transformations? 


\section{LITERATURE REVIEW}

Theorizing about resilience has grown in importance as we try to learn how to adapt in the face of social, ecological, and economic change; however, identifying when and how a system is resilient remains remarkably elusive, or at least hotly contested. When Holling first defined resilience in an ecological context in 1973, he emphasized the persistence of relationships, absorption of changes, and persistence within the parameters of a system. Although this provided subsequent researchers with the parameters of a concept, despite decades and growing attention, as late as 2006, Folke described research into social-ecological resilience as "still in the explorative phase" (p. 262); his emphasis on social networks and adaptive governance were prophetic, even as calls for further theorization of the social dimensions of resilience appear periodically (Brown 2013).

Burkhard et al.'s (2011) modified loop, with a modified or "squiggly" path from exploitation to conservation, and Fath et al.'s (2015) further qualifications on this modification (status quo ante to crisis to confusion to innovation to new growth to status quo) are very promising for frustrated social innovation scholars. Further work has been conducted looking at system resilience in a historical context, identifying changes in social systems post hoc, rather than seeking to understand the processes that brought them about (Mumford 2002, Godin 2012, McGowan and Westley 2015, Westley et al. 2017).

Measuring system resilience faces two critical conceptual challenges. First, there is the problem of bounded rationality (Simon 1982). We can only plan and make decisions about those parts of a system we have some understanding of, and the process of learning about a system is itself costly. The issue of bounded rationality may help explain the tension between decisions made to support specific resilience at the expense of general resilience, observed by many (Holling et al. 1998, Walker and Westley 2011). The specific resilience in question may simply be easier to grasp or assess, whereas cumulative problems that could lead to collapse and transformative change may be too diffuse to easily observe.

Second, there is no actor in a system that can actually play the role of omniscient superobserver (Ahl and Allen 1996). In effect, any actor who tries to understand or measure any element of a system is necessarily a part of that system. Measurement itself changes how the system operates. Taken together, these conceptual challenges mean that we are unlikely to find a straightforward way of understanding what is happening in a complex system as it undergoes a transformation or responds to a systemic shock by maintaining its overall structure. Furthermore, as elements of these systems, those who were a part of a social system as it was going through a crisis are unlikely to have a clear way of understanding the system's resilience while it is undergoing a transformation. Instead, in the face of uncertainty and complexity we would expect to see an iterative learning-bydoing process as agents in the system try to understand the changing world around them (Arthur 1994). That said, this learning process is largely taken at an individual level, rather than at a larger social level.

An initial tempting hypothesis may be that these difficulties are a question of cross-discipline translation, from ecology to social science, for which hypothesis there is supporting evidence. There exists tension between different fields' utilization of resilience as a covering concept, so much so that across even specific disciplines "a common definition has proven elusive" (Jackson et al. 2007:3) beyond it being "positioned interdependently from adversity" (Jackson et al. 2007:3). This highlights a greater problem across and within disciplines: If we are unsure of our goal, we are similarly unsure of its effective proxies. Take those interested in personal resilience (those studying workplaces, childhood, student and adult psychology, for instance), where there is ambiguity or lack of agreement as to whether to measure chemical responses, characteristics, or processes (Tugade and Fredrickson 2004, Jackson et al. 2007, Smith et al. 2008, McDonald et al. 2012, Yeager and Dweck 2012).

These disagreements are replicated in the emergence and refinement of several scale systems to measure personal resilience, discussed here in a few examples. The Connor-Davidson scale (2003) measures responses on 25 questions (each on a five point scale) focused on self-reported "personal qualities that enable one to thrive in the face of adversity" (Connor and Davison 2003:77-78) and the contemporary Resilience Scale for Adults (Friborg et al. 2003) considers five dimensions the authors associate with protective resources for health adjustment: personal competence; social competence; social support; family coherence; and personal structure. Much simpler, the Brief Resilience Scale asks respondents six questions that focus on the ability "to bounce back or recover from stress" (Smith et al. 2008:199). Although the focus on response/recovery is clearly common, little else is, and regardless, these variant personal resilience measures cannot be assumed to scale to a complex social system, in part because of that complexity. Although a social system may be made up of people and their rules, the interactions therein "often produce phenomena that are more than the parts" and are instead emergent (Page 2010:12).

We should not be surprised at the difficulty in finding answers to our questions about resilience across the disciplinary boundaries. Folke pointed to difficulties of interdisciplinary translation in 2015 and said that the concept as a result was "sometimes interpreted in ways that fit old paradigms and discourses" (as cited in Biggs et al. 2015:xii-xiii). Yet, in the first case, the need for clarity and coherency in the field of ecological resilience, especially social-ecological resilience, has been demonstrated in several recent efforts at synthesis. These include Biggs et al.'s (2015) seven principles for building social-ecological resilience: maintain diversity and redundancy; manage connectivity; manage slow variables and feedbacks; foster complex adaptive systems thinking; encourage learning; broaden participation; and promote polycentric governance. The role of resilience (obtaining resilience and/or supporting resilient capacity) has become increasingly common in framing policy, practical, and even educational responses to the Anthropocene (IPCC 2012, Olsson et al. 2017, Moore et al. 2018, Silverman and Hill 2018, StoneJovicich et al. 2018, van Zwanenberg et al. 2018).

The principles Biggs et al. (2015) presented are distinctly forward looking, based in data but filtered through the lens of how we can obtain sustainability; the implicit and explicit consequences are likely true, but analytically problematic. Separating ecological and social resilience is artificial and arbitrary (Berkes and Folke 1998), regardless of the methodological issues. Hence, Folke et al. (2016) repeat and refine Holling's 1973 definition, that social- 
Table 1. Panarchy, ontological and epistemological, and the Plague.

\begin{tabular}{|c|c|c|c|}
\hline Phase & Ontological Phenomena & Epistemological Phenomena & Plague Examples \\
\hline \multirow[t]{2}{*}{ Collapse } & $\begin{array}{l}\text { Old "strange attractor" ceases to organize } \\
\text { dynamic system }\end{array}$ & $\begin{array}{l}\text { Status quo system indicators used, likely } \\
\text { more stringently even as anomalies } \\
\text { accumulate }\end{array}$ & Mass death \\
\hline & & & $\begin{array}{l}\text { Contemporary observers remark on } \\
\text { social collapse } \\
\text { Flagellants and pogroms }\end{array}$ \\
\hline \multirow[t]{3}{*}{ Reorganization } & $\begin{array}{l}\text { Connections between system elements are } \\
\text { broken, system appears chaotic and multiple } \\
\text { potential strange attractors emerge }\end{array}$ & Status quo indicators are questioned & Laws attempt to reinforce status quo \\
\hline & & & Wills and burials continue \\
\hline & & $\begin{array}{l}\text { Personal narratives are the primary way } \\
\text { of understanding the system }\end{array}$ & Writers' assessment of their own era \\
\hline \multirow[t]{3}{*}{ Exploitation } & $\begin{array}{l}\text { A strange attractor has emerged, although it } \\
\text { is not yet clear to those within the system } \\
\text { what the system will look like in its stable } \\
\text { form }\end{array}$ & $\begin{array}{l}\text { Shared narratives and pluralist } \\
\text { understandings emerge }\end{array}$ & Peasant revolts \\
\hline & & & Availability of land \\
\hline & & & Access to capital shift \\
\hline \multirow[t]{4}{*}{ Conservation } & Dynamic system organized around new & Common measures/frameworks emerge & Emergence/solidification of \\
\hline & strange attractor & to describe the system & Parliament (England) \\
\hline & & & Urbanization in Europe \\
\hline & & & Serfdom in Russia \\
\hline
\end{tabular}

ecological resilience represents the capacity to transform "in ways that continue to support human well-being." Although this is deeply appealing, understanding the process of how collective narratives are built during a crisis remains underexplored.

\section{Analytical framework}

To explore this process of individual to collective narrative formation, and the possibilities of measuring systems resilience, we have mapped the Plague and its aftermath over the four stages of the adaptive cycle (Holling and Gunderson 2002), starting with collapse, through reorganization, exploitation, and conservation. Mapping events over the cycle has been an imperfect process and sets up a tension between the ontology of social transformation and the epistemology of social transformation. In Table 1, we have mapped ontological and epistemological phenomena and possible Plague-related examples. From complexity theory, the concept of a "strange attractor" is brought in (Prigogine and Stengers 1984). Attractors are a feature that the behavior of a system tends toward and in designed systems are usually explicitly planned. Strange attractors arise in complex systems where they are not tied to specific periodic behavior nor are they explicitly outlined. Instead, they emerge from the complex interactions between system elements and describe the ways that complex dynamic systems can remain together without central direction or organization.

There appears to be a time lag between the two: the epistemological phenomena occur after the ontological phenomena. Incentives structures change and then there is a lag between those changes and how actors can respond. Indeed, because the new selection pressures that arise during this reorganization are largely opaque to those actors living through them, they are often unable to change their behavior before these pressures lead their organizations to also collapse. However, these selection mechanisms take time for their impact to be felt, and organizations that have accumulated ample resources can last for decades before falling apart even when their nonviability is clear.

\section{METHODS}

Through an examination of academic research relying on contemporary accounts and records of the Plague's first journey through Europe (1347-1351), we examine the indicators Europeans used at the time to understand changes in their socialecological systems.

\section{Data}

The Plague has inspired significant academic attention over the past two centuries (indeed, the term "Black Death" is a more recent mistranslation, not a contemporary term, something authors frequently relish pointing out). Our data set comprises 50 entries from the most recent half-century of this prodigious production, specifically peer-reviewed journal articles and monographs published in 1967 and after. This period was chosen for several reasons: first, the RAND report mentioned above was published in 1966; second, available data collections are relatively stable in this period (one significant change was the discovery through archaeological DNA that the Plague was in fact Yersinia pestis), therefore reducing the likelihood that different interpretations of contemporary resilience were solely a function of the sources available to historians; and, third, there were sufficient manuscripts available to minimize overemphasizing a single author's point of view.

To address this last concern, when an author published several articles and monographs, preference was given to monographs over articles (hence more comprehensive), and recent publications over older ones (hence more likely to reflect current research). If an author wrote two books that contradicted each other, preference was given to that work that represented a more complete and more up-to-date consideration of available sources. Authors were revisited if they shifted the focus of their analysis to a different set of primary data, hence allowing us to broaden the scope of the contemporary perspectives on resilience. Additionally, multiple manuscripts were excluded because of the lack of any relevant discussion of contemporary resilience 
(especially archaeological studies focused exclusively on DNA, for instance). In all cases, our focus was primarily on how historians used and interpreted the primary data available to construct cases for and against the resilience of medieval society, and what the data itself suggested, particularly in the aggregate. This is far from a simple task, as Ziegler (1969:34) noted, "in medieval history, it sometimes seems that the more precisely a question is defined, the more certain it is that no answer will be forthcoming." To manage this problem, we coded our sources according to the criteria outlined in Table 2.

Table 2. Coding by source.

\begin{tabular}{lcc}
\hline \hline Item & $\begin{array}{c}\text { Data } \\
\text { derived }\end{array}$ & $\begin{array}{c}\text { Historical } \\
\text { Analysis/ } \\
\text { Framework }\end{array}$ \\
\hline $\begin{array}{l}\text { Contemporary awareness of social } \\
\text { resilience }\end{array}$ & $\mathrm{x}$ & \\
$\begin{array}{l}\text { Key agents trying to understand the system } \\
\text { Social systems under examination } \\
\text { Time horizon/Temporal scale }\end{array}$ & $\mathrm{x}$ & $\mathrm{x}$ \\
$\begin{array}{l}\text { Geographical scale } \\
\text { Analytical perspective on systems resilience }\end{array}$ & & $\mathrm{x}$ \\
& $\mathrm{x}$ \\
\hline
\end{tabular}

This distinction between data and analytical frame is important broadly and specifically. Broadly, when using secondary sources we do not want to mistake analytical choices for historical reality, as, "Paradoxical as it may sound, the lesson of history is that all too often people find it easier to manipulate the facts to fit their theories than to adapt their theories to the facts observed" (Cohn 2003:54). Specifically, historians have identified (but done little to rationalize) a tension between regional, which may be diametrically opposed from one another, and continent-wide conclusions about the Plague's impact (Cohn 2007a). Cohn himself attributed this incongruence to historians being overly guided by chroniclers, and yet, as demonstrated below, the larger picture of disruption has largely been resilient itself to historiography. That small-scale resilience leads to large-scale disruption seems to beg further analysis.

\section{RESULTS}

\section{The problem of the 14th century}

Understanding the social, political, economic, and cultural effects of the Plague extends beyond simply assessing the available data. It was, according to one contemporary, a time marked by "strange and great perils and adversities" (as cited in Tuchman 1978:xii). Tuchman (1978) presented the Plague as a middle moment in a century of self-inflicted pain in Europe, one of an expanded seven horsemen of the seeming apocalypse: "plague, war, taxes, brigandage, bad government, insurrection, and schism in the Church" (p. xiii). Only the first of these was exogenous, but all were deeply threatening to the medieval systems.

The RAND report (Hirshleifer 1966:2) was aware of this problem: "The effects of the pestilence are not easily separable from those of the destructive Hundred Years' War; in addition, the Western European nations and especially England and France suffered also from internal dynastic conflicts, class warfare, and regional separation ... overall lessons to be drawn from complex phenomena such as disaster-recovery experiences must, necessarily, be in large part subjective and impressionistic." This also fueled several authors downplaying the influence of the Plague itself as a discreet disruptive event, because of a perceived extended period of crisis (Zeigler 1969, Bowsky 1971, Davis 1986, Noymer 2007, Pamuk 2007, Campbell 2016). Another important question is population. In the mid-century historians debated the question of whether Europe was trapped in a Malthusian crisis, where arable land was essentially at full capacity and could no longer support population growth. Although the historical record is far from settled, it does certainly suggest a rigidity trap (Holling and Gunderson 2002) or a lack of capacity to develop. This, in turn, may contribute to a brittleness.

Therefore it is possible to consider 14th century European society as far from resilient before the Plague, or possibly primed for a fall into collapse independent of the Plague, and this one external catalyst must therefore be contextualized. As the Plague spread across a many brittle European social orders, local accounts produced across the continent provide data that helps us understand how people perceived their own societies' resilience in the face of real-time disruption.

\section{Perceiving a transition}

Taking into account the issues above, we looked for indicators that would be directly affected by the immediate population loss, including rents, wages, and death-related processes (wills, burials, heriots). Across a wide geographical spectrum, we found a generalized time lag between quantitative indicators of system resilience and the systemic shocks introduced by the Plague. This lag is partly a function of institutional forces and the exercise of power in an attempt to maintain system stability, partly because of how demographic disruptions temporarily worked on the strange attractors of the Medieval European order to keep it in place, and partly from the slow emergence of distinct new Early Modern strange attractors that ultimately would serve as an alternative order. Because the Plague left political systems largely in place, they could respond to the crisis conservatively, seen most clearly in England but also elsewhere, where legislatures and crowns sought to enforce pre-Plague prices and wages, and even pre-Plague social controls.

There are similar continuances of burial ceremonies and will practices, particularly in cities as described in records from the time: "it is in the mundane and highly formulaic notarial records that we find the most vivid evidence for the management of life during a time of overwhelming death ... the making of a will marked an act of continuity, of concern for the perpetuation of the family in the future and the journey of the soul to the next life" (Wray 2009:6-7). However, and in direct contrast with the majority of contemporarily derived data sets, narratives from the time suggest that those who were experiencing the epidemic were trying to develop personal understandings of the social changes around them and collective understandings of how to respond to these crises, both in advance of collecting easily comparable data that could be used for broader administrative purposes. To more effectively communicate this tension, consider how different indicators help us understand the Plague's effects over time according to collapse, reorganization, and exploitation. 


\section{Collapse (six months)}

When a system enters collapse, the old strange attractors no longer hold it in dynamic tension, but traditional indicators are used, even as they lose explanatory power or metric relevancy. As the Plague traveled across Europe, and killed waves of people, we see both a belief expressed that the entire set of linked systems that characterize Medieval Europe have disappeared or become unmoored, but interestingly traditional ontological views not only remained largely in place, but were looked to for possible solutions.

Although the Medieval period was not one remarkable for popular literacy, chroniclers and moralists avidly and regularly wrote for posterity. Despite hyperbole being in vogue, "[they] should, nonetheless, be taken seriously" (Cesana et al. 2017:17), although Hirshleifer (1966) criticized chroniclers for their focus on exceptionality. Of course, in the context of observing a Plague, this critique lands as a bit unfair. What the chroniclers captured about the Plague is a society in free fall. Zeigler (1969:83) summarizes this quite succinctly: "With no future to await, and the threat of annihilation hanging over all he cared for, how could medieval man be expected to behave with responsibility?" There may have been no one to hear or judge this irresponsibility: "For god is deaf nowadays and will not hear us. And for our guilt he grinds good men to dust" (as cited in Cantor 2001:6). Magnus IV, King of Sweden, similarly saw God's wrath: "God for the sins of men has struck the world with the great punishment of sudden death. By it, most of our countrymen are dead" (as cited in Gottfried 1983:57)

Agnolo di Tura was brief: "This is the end of the world" (as cited in Kelly 2005:26). Ralph of Shrewsbury, then Bishop of Bath and Wells Petrarch, seemingly slightly more optimistic that there would be a future, declared, "O happy posterity, who will not experience such abysmal woe and will look upon our testimony as a fable" (as cited in Benedictow 2004:3). Guillaume de Machaut was less emotionally charged, but equally despairing of what he saw: "for the lack of people many a splendid farm was left untilled. No one plowed the fields bound the cereals and took in the grapes, some gave triple salary but no for one denier was twenty [enough] since so many were dead" (as cited in Herlihy 1997:41). Jean de Venette similarly saw "many houses in good towns remained empty and deserted" (as cited in Gottfried 1983:56).

Although chroniclers provide florid descriptions, Platt (1997:177) reminds us that within these sources "the poor are usually silent, and almost nothing can be known about their feelings." This should give pause: How representative can we treat the chroniclers' declarations? Two populist religious movements may help resolve this question, in part. Placing the Flagellants and pogroms in collapse, rather than reorganization, is based on an observation from Slack (1988:439), "both reactions had precedents in the past and were reflections of the contemporary assumptions: first that Plague was a punishment for sin, and second, that it was brought into a community by outsiders." Ergo, as individually remarkable as the crowds of partially naked, bleeding people traveling from town to town and whipping themselves (and by metaphorical extension the observant crowds) in a frenzy might seem, both the persecution of innocent Jewish communities and flagellation can be understood as expressions of popular social anxiety (Cohn 2007b) seeking to restore spiritual/sin equilibrium with God.

Unlike the peasant revolts to be discussed below, attacks on the Jews included no particular "challenge political authority or question of prevailing social hierarchies," but instead happened with the support and often explicit encouragement of elites (Cohn 2007b:7). Contrary to the narrative provided by many historians, the Plague was not an ontological shock. Although the benefit of centuries of scientific discovery allow us to know how inappropriate and ineffective their prescriptions were, medievals were used to death, and used to perceiving God's punishment or judgment in tragedy or the unexplained. Although the effects of Jewish persecution (morally, economically, socially, etc.) may be traced down the centuries to modern atrocities (Jedwab et al. 2016), the showy and evocative Flagellants may be exaggerated in their popularity and "did not, in the long run, amount to much " (Ziegler 1969:86). By this Zeigler means they made little influence on everyday religious practice.

\section{Reorganization (3 months to 10 years)}

After the demographic shock, what new strange attractors emerge? What metrics captured these processes, and how did the people of Europe seek to make sense of what just happened? In this period, we see the most narrative and evidentiary ambiguity around the Black Death; historians fault the chroniclers here, for chronic exaggeration, but this may be unfair, as they seek to make sense of something awesome.

In the medium term ( 1 to 10 years), many historians found a relatively high degree of resilience, especially if we look to the basic need to maintain basic functions. "The ability of plague survivors to recover and re-invigorate their time-honored customs and beliefs allowed for continuity and a more gradual transition than the artificial dividing lines between the medieval and early modern periods suggest" (Aberth 2005:4). The degree to which things seemed to return to normal has led at least one historian to speculate that the death rates must be highly exaggerated: "Obviously there is a fallacy somewhere-and it must be in the greatly exaggerated estimates of mortality because there were no deserted villages; there was no interruption in agriculture or land tenure; there was no appreciable change in the manner and customs of English life, and no interruption of the war with France!" (Shrewsbury 1971:123) This seeming resilience is a function of the chaotic and unclear reorganization phase, where no one new set of strange attractors had emerged, but nor were the previous ones unassailable; it is open season.

There is significant ambiguity in the economic data, as the effects of the death were unevenly distributed, and filtered through extant political systems. Here we start to see spikes in real wages (J. H. Munro 2004, unpublished manuscript) and (temporary) economic efficiencies (Clark 2016). Although some find wage fluctuations, those numbers are often incredibly uneven across Europe. This may be attributable to policies (Britnell 1990, Sloane 2011, Braid 2013), and in some cases (England) speaks to the absence of any immediate threat to the political system, differential market conditions (Caferro 2013), manorial practices (Campbell 1997), differential death rates, and even the interplay of wages, deaths, and surprisingly stagnate prices (Campbell 1997). Cohn (2007a) found that some laws were enforced, but others not (notably in 
Florence), and that price divides could split cities from the surrounding countryside. In the case of wages, Britnell (1990:28) called this the "Feudal reaction," where at "the highest levels of authority, measures were taken by the central government to offset the effects of rising wages ... [and] landlords exercised their power on individual estates."

Taken from a continent perspective, these laws "defy any obvious patterns of economic or political rationality" (Cohn 2007a:457). This reflects the ambiguity of strange attractors in the aftermath of the death, which at some level people understood: "Ruling elites across Europe saw the Black Death abruptly posing new threats to social mores and the political and economic structures of the pre-Plague era. The supposed 'greed' of workers and artisans was one such threat that elites feared" (Cohn 2007a:481).

So, if quantitative signals were at best confused in this period, what of the personal storytelling? The Decameron was completed in this time period (by 1353), and Boccaccio provided an extensive description of the Plague's impact on Florence. It is too long to be excerpted here, but consider one portion: "The wisest of men do not learn patient acceptance of life from the small-scale, intermittent disasters that occur in the natural course of events, but the sheer scale of the current calamities taught even simple people how to bear things with stoical indifference" (translation, Boccaccio 2015:16). Boccaccio questioned the capacity of local doctors, but Wray (2004) suggests this was both unfair and not exactly Boccaccio's message, that instead the poet was linking a physical disease with a diseased society, demonstrated through a lack of compassion and ultimately abandonment. Wills do not necessarily support Boccaccio's condemnation, but his was not an uncommon belief, that people had abandoned loved ones and duty in the time of Plague.

Petrarch's fabled love, Laura (or her real life inspiration), died in the Plague. Though Petrarch spent 1350-1351 travelling to find "a tranquil retreat in an unsatisfactory world," as he aged he subsumed the Plague into the social and moral ills he diagnosed around him (Watkins 1972:203). Whereas many initial comments (seen in collapse) were literally apocalyptic, we see in these comments attempts to make sense of survivorship, and to integrate the Plague into a wider narrative, symptomatic of general malaise.

\section{Exploitation (10+ years)}

Shifts in rural economy over the long term emerge slowly (the gradual transition Aberth [2005] identifies), and unevenly, depending on how time influences the alignment of new strange attractors. This is most apparent in economic relationships, which often seem to have taken significant time to realign. Although real rents stayed more or less flat, rather than declining (Clark 2016), Haddock and Kiesling (2002:582) argue serfs became less and less financially attractive in England:

Serf labor was a form of communal property. As with other forms of communal property, joint ownership rights generated some dissipation, but as long as the marginal product of labor was low, the value dissipated was relatively unimportant and would not support a substantial control cost. As labor grew dramatically scarcer across the many plague decades, the marginal value of the dissipation grew.
Similarly, DeWitte (2014b:2) identified 1375 as the date when prices on goods dropped "steeply" in that same country, which then became the new norm until the middle of Henry VIII's reign, and she identified a similar pattern with wages.

Kitsikopoulos (2002) attributed a long-term improvement in peasant living standards to smaller families and fewer seigneurial dues. This is in spite of the inflation and price equilibrium described above, and highlights the social consequences of Haddock and Kiesling's (2002) shifting economic calculations. In one spectacular case, we see a correction of the feudal reactionontological and epistemological factors combining in bloodshed: the 1381 Peasants' Revolt in England. As discussed above, England was one of the jurisdictions to introduce laws to try to restore and reinforce pre-Plague political-economic relationships, which England also prosecuted, "frequently and with some success" (Dobson 1983:69).

Several historians have noted the widespread destruction of manorial records including tenants' obligations and attacks on justices of the peace who tried cases under the Statute of Labourers or provided strong evidence of landed gentry struggling under tight labor market conditions. Taken together these are the clearest connection between the manifestation of a revolt period in a system change process and the Plague-caused disruptions (Dobson 1983, Hilton 2003). The Feudal Reaction had played itself out, running up against the epistemological realities of a changing system: "Eventually the lords' attempts to use the legal system to cartelize conditions of servitude generated revolt among the peasants" (Haddock and Kiesling 2002:584).

\section{Conservation (one generation+)}

The question of whether or not a system is resilient can be reframed, post hoc, as a set of subquestions about whether or not the system has fundamentally changed. Do we see a new dynamic system, arranged around new strange attractors, or has the system successfully learned to forgive and reorient, but stay fundamentally in the original dynamic tension? Do we see new indicators and frameworks emerge?

Geography and temporal dynamics are clear in the conservation phase, as different subregions of Europe seem to have crystallized differently, even divergently. One historian declares that the existence and ultimate failure of the revolt cemented the capitalist farming system, one without serfs but that was also deeply patriarchal, and that lasted until the Industrial Revolution (Hilton 2003); this was the "golden age of peasants and labourers" Hatcher described (2009:320-321). Palmer (1993) sees the path dependency toward centralized (Tudor) governance; this was, in Palmer's eyes, the equal and opposite effects of the Statute of Labourers, that laws passed to maintain medieval economic order tipped it toward a more modern system of governance. Notably, Henneman (1968) sees the opposite path in France, that concessions made in the aftermath of the Plague to maintain royal finances set that crown on an irreversible path of structural economic problems. Similarly, Langer (1975) asserted that the Plague tipped Russia into long-term serfdom, as population loss and recovery from the Golden Horde combined to make forced labor preferable, encoded, and the norm. This is not the collapse of one stable equilibrium and the gradual shift toward another stable equilibrium. Instead, we observe the collapse of dynamic equilibria and the emergence of multiple, path-dependent alternatives. 
Several authors suggest that ultimately the Plague changed the "character" and/or "value system" of European populations (Bowsky 1971, Herlihy 1997, Platt 1997, Kelly 2005, DeWitte 2015). Cohn (2003) provides a more coherent conclusion here, that the Plague's effects "give expression to a new Renaissance psychology, one grounded in hope and hubris" (p. 252), which he associates with the drive for fame and glory associated with exploration, innovation, and invention. This new mind-set, and new norms, would be the core of a new system-Renaissance Europe. These conclusions support neither resistance to change nor resilience of the medieval system, but a new set of strange attractors, with new possible innovations, new organizations, and processes.

\section{DISCUSSION}

The above panarchy framework of the Plague raises certain key questions about evidence, scale, and the cycle itself. Starting with the cycle itself, there is not necessarily a strong distinction between collapse and reorganization, particularly when we move beyond the initial experience of the Plague and consider the epistemological phenomena associated with the two periods. It is possible that collapse can be an elastic experience, whose duration shifts over context, and possibly over time, as memory creates a linear narrative. It is also possible that the two periods may overlap as the experiences of a shock may be unevenly felt and understood across different organizations and institutions within a social system. This may also be taken as evidentiary support for Fath et al.'s (2015) modified cycle, especially their distinction of crisis and confusion from collapse. Interestingly, though, the evidence from the 14th century seems resistant to discrete periodization, suggesting a degree of simultaneous experience.

Scale presents us with another conundrum. As discussed above, often locally focused studies find high degrees of resilience, while travelling up scales suggests greater disruption. Even in the conceptualization offered above, generally collapse and conservation are framed at the landscape, and reorganization and exploitation at regional levels. This poses several questions: Is it possible that changes happen more slowly at the local level? Are metrics of resilience at a local level different enough from ones at a societal level that small-scale resilience can be partially decoupled from wider systems disruption? Or is this a structural problem, that those areas with a strong enough documentary record are exceptions, less hurt by the Plague and perhaps more resilient (ergo, not a general phenomenon, but a few unique examples)? This question requires further exploration, and is a possible question for future research.

Despite the above issues, there are a few general conclusions we can take from the Plague as panarchy discussion. First, there is a generalized pattern of observation over time. The accidental Jcurve in Figure 1 is attractive, but presents us with a fundamental problem; the farther forward in time, the less likely the sense of disruption is being measured among the same actors, thereby undermining its validity. It stands to reason that later generations would see things differently than their parents did, and it limits our analysis of economic and political systems. Unfortunately, there are no independent superobservers we can appeal to for clarity (Ahl and Allen 1996). In effect, we are limited by a window of understanding. It opens as we move some distance in time from the triggering event, but then slowly closes as our distance from it moves the event from history and into allegory.
Fig. 1. Sense of disruption over time.

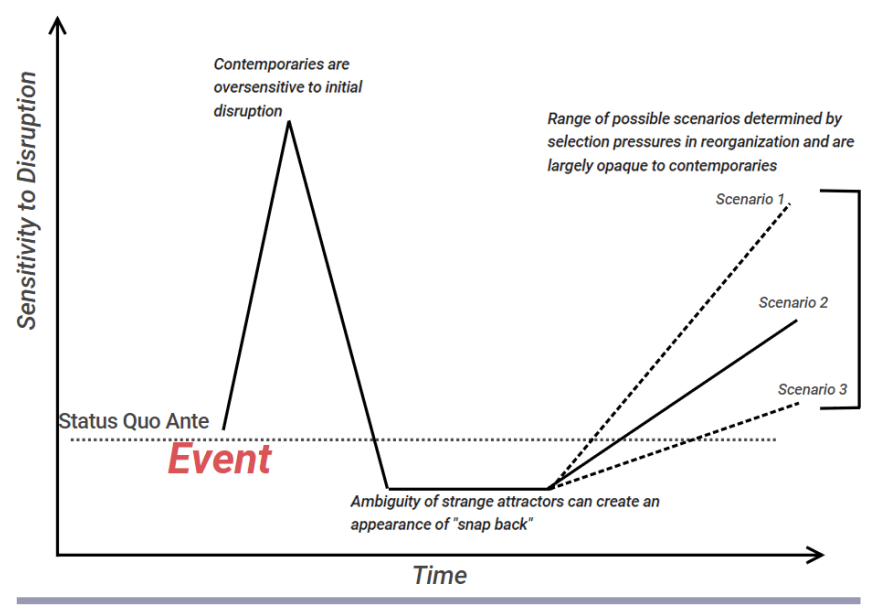

Although the Feudal Reaction may suggest economic systems could follow a similar pattern, a two-dimensional graph is likely inappropriate. Instead, the cumulative effects of the demographic loss can be understood as ripples in the system, disrupting its dynamic tension and driving specific directions based on the interplay of context and change.

Figures 2 and 3 consider Russia and England's respective economies and political systems, and demonstrate how the Plague created deep ruts that produced divergent outcomes. This is demonstrated in Exploitation and Conservation above. Russia and England are excellent comparisons in terms of extremes, and there are valid questions about using national boundaries (not in

Fig. 2. Russia, over time.

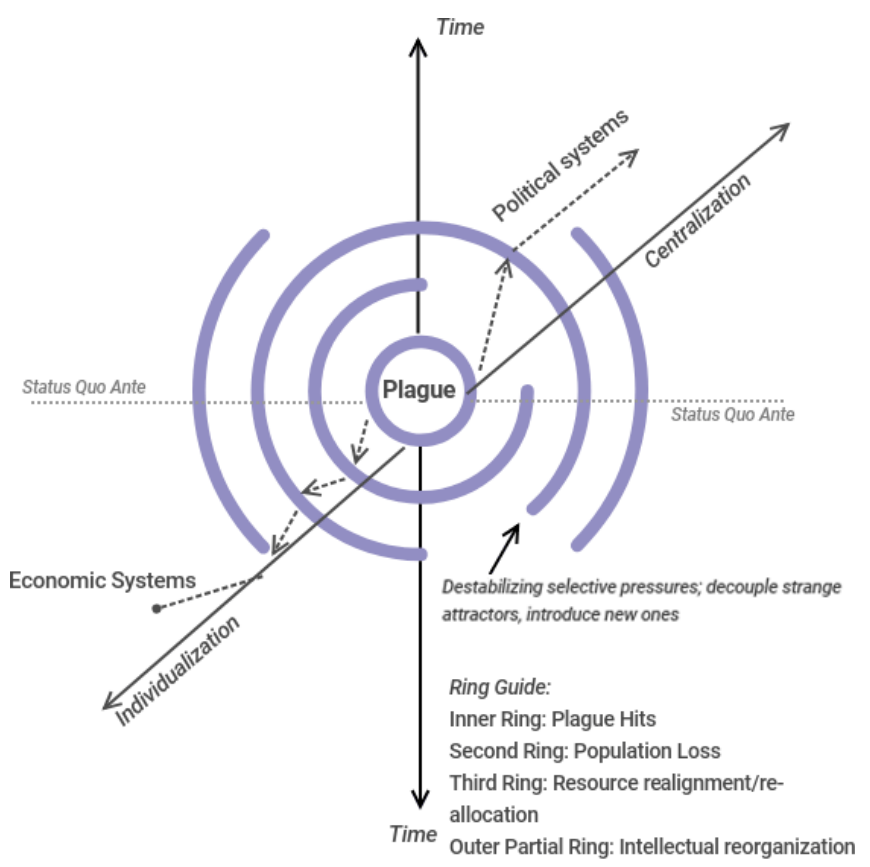


Fig. 3. England, over time.

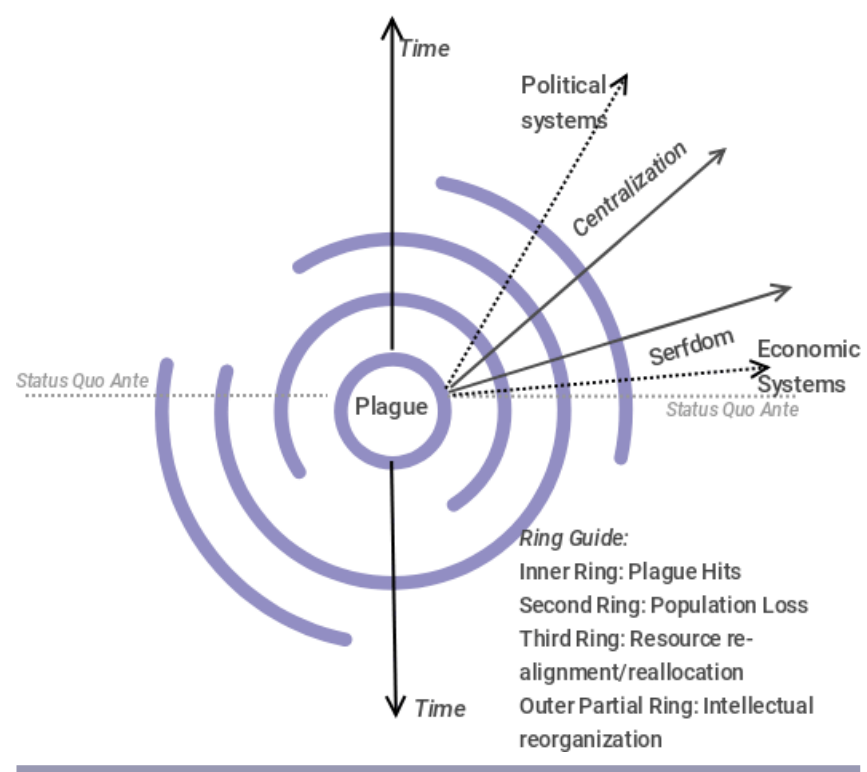

the case of England) because many modern states did not exist and historical ones can be difficult to map over time (Burgundy, for instance). Yet the data strongly suggests that by the Conservation phase we see many smaller systems, held in dynamic tension by different strange attractors, although all experienced the Plague's disruption, and its effects over time.

Perhaps most importantly, however, from the moment of the Plague's arrival, there is a progression from individual narratives, to common understandings, and finally to comparable data. The latter is likely a common process that occurs as those within a social-ecological system make sense of a shift of the system from one arrangement to another. Although Boccaccio and Petrarch had unusual access to posterity, the Peasant Revolt in England may be considered as following a similar pattern. At first, individuals sought improvements in their working conditions (those "unreasonable wages"); the Revolt itself was a form of collective action, each individual narrative moving into a common understanding for change.

This was against the legal and political systems' efforts to disrupt emerging signals that the organizations of the previous system were no longer working, no longer meeting the requirements of the system parts, and that doubling down, so to speak, was not successful or prudent. Although the Revolt itself was not successful in the immediate sense, it was impossible to return to the status quo ante, and the new, more capitalist agrarian economy had emerged.

\section{CONCLUSION}

At the moment of the Plague's arrival, it may have seemed like the world was over, as one observer suggested. The Plague has been used to understand the aftermath of the First World War, the possibility of world-ending Nuclear War, and epidemics like AIDS and SARS; it is a parable of resilience for every era's fears, sometimes for and sometimes against the survival of a complex social system. Petrarch was right: We look upon their experiences as fables.
On their own terms, Medieval Europeans expressed personal understandings of the social changes around them, often hyperbolic, but that set them on a course toward collective understandings of how to respond to these crises. The progression from individual narratives, to common understandings, and finally to comparable data is likely a common process that occurs as those within a social-ecological system make sense of a shift of the system from one arrangement to another. The Plague teaches us about how people have responded to, and how we have thought about, societies in crisis. From it we can learn the limits of what we can understand during our current period of social transformation and what we will have to rely on descendants to reveal.

Responses to this article can be read online at: http://www.ecologyandsociety.org/issues/responses. php/11089

\section{LITERATURE CITED}

Aberth, J. 2005. The Black Death: the great mortality of 1348-1350, a brief history with documents. Bedford/St. Martins, Boston, Massachusetts, USA.

Ahl, V., and T. Allen. 1996. Hierarchy theory: a vision, vocabulary, and epistemology. Columbia University Press, New York, New York, USA.

Arthur, W. 1994. Inductive reasoning and bounded rationality. American Economic Review 84(2):406-411.

Benedictow, O. 2004. The Black Death, 1346-1353: the complete history. Boydell, Suffolk, UK.

Berkes, F., and C. Folke, editors. 1998. Linking social and ecological systems: management practices and social mechanisms for building resilience. Cambridge University Press, Cambridge, UK.

Biggs, R., M. Schlüter and M. L Schoon, editors. 2015. Principles for building resilience: sustaining ecosystem services in socialecological systems. Cambridge University Press, Cambridge, UK. https://doi.org/10.1017/CBO9781316014240

Boccaccio, G. 2015. Tales from the Decameron. P. Hainsworth, Translation. Penguin Books, Milton Keyes, UK. (Original work published c. 1351).

Bowsky, W., editor. 1971. The Black Death: a turning point in history? Holt, Rinehart \& Winston, New York, New York, USA.

Bridbury, A. R. 1973. The Black Death. Economic History Review 26(4):577-592. https://doi.org/10.2307/2593699

Britnell, R. H. 1990. Feudal reaction after the Black Death in the Palatinate of Durham. Past \& Present 128(1):28-47. https://doi. org/10.1093/past/128.1.28

Braid, R. 2013. Behind the ordinance of labourers: economic regulation and market control in London before the Black Death. Journal of Legal History 34(1):3-30. https://doi.org/10.1080/01440365.2012.730244 
Bridbury, A. R. 1973. The Black Death. Economic History Review 26(4):577-592. https://doi.org/10.1111/j.1468-0289.1973.tb01955. $\underline{x}$

Brown, K. 2013. Global environmental change 1: a social turn for resilience? Progress in Human Geography 38(1):107-171.

Burkhard, B., B. D. Fath, and F. Müller. 2011. Adapting the adaptive cycle: hypotheses on the development of ecosystem properties and services. Ecological Modelling 222(16):2878-2890. https://doi.org/10.1016/j.ecolmodel.2011.05.016

Caferro, W. 2013. Petrarch's War: Florentine wages and the Black Death. Speculum 88(1):144-165. https://doi.org/10.1017/ $\underline{\mathrm{s} 003871341300050 \mathrm{x}}$

Campbell, B. M. S. 1997. Matching supply to demand: crop production and disposal by English demesnes in the century of the Black Death. Journal of Economic History 57(4):827-858. https://doi.org/10.1017/S0022050700019550

Campbell, B. M. S. 2016. The great transition: climate, disease and society in the Late Medieval world. Cambridge University Press, Cambridge, UK. https://doi.org/10.1017/CBO9781139031110

Cantor, N. 2001. In the wake of the Plague: The Black Death and the world it made. The Free Press, New York, New York, USA.

Cesana, D., O. J. Benedictow, and R. Bianucci. 2017. The origin and early spread of the Black Death in Italy: first evidence of plague victims from 14th century Liguria (northern Italy). Anthropological Science 125(1):15-24. https://doi.org/10.1537/ ase. 161011

Clark, G. 2016. Microbes and markets: was the Black Death an economic revolution? Journal of Demographic Economics 82:139-165.

Cohn Jr, S. K. 2003. The Black Death transformed: disease and culture in early Renaissance Europe. Arnold/Oxford, London, UK.

Cohn Jr, S. K. 2007a. After the Black Death: labour legislation and attitudes towards labour in late-medieval western Europe. Economic History Review 60(3):457-485. https://doi.org/10.1111/ j.1468-0289.2006.00368.x

Cohn Jr, S. K. 2007b. The Black Death and the burning of the Jews. Past and Present 196(1):3-36. https://doi.org/10.1093/pastj/ gtm005

Connor, K. M., and J. R. T. Davidson. 2003. Development of a new resilience scale: the Connor-Davidson resilience scale (CDRISC). Depression and Anxiety 18(2):76-82. https://doi. org/10.1002/da.10113

Cote, M., and A. J. Nightingale. 2012. Resilience thinking meets social theory: situating social change in socio-ecological systems (SES) research. Progress in Human Geography 36(4):475-489. https://doi.org/10.1177/0309132511425708

Cretney, R. 2014. Resilience for whom? Emerging critical geographies of socio-ecological resilience. Geography Compass 8 (9):627-640. https://doi.org/10.1111/gec3.12154

Davis, D. E. 1986. The scarcity of rats and the Black Death: an ecological history. Journal of Interdisciplinary History 16 (3):455-470. https://doi.org/10.2307/204499
DeWitte, S. N. 2014a. Health in post-Black Death London (13501538): age patterns of periosteal new bone formation in a postepidemic population. American Journal of Physical Anthropology 155:260-267. https://doi.org/10.1002/ajpa.22510

DeWitte, S. N. 2014b. Mortality risk and survival in the aftermath of the Medieval Black Death. PLoS ONE 9(5):e96513. https:// doi.org/10.1371/journal.pone.0096513

DeWitte, S. N. 2015. Setting the stage for medieval plague: preBlack Death trends in survival and mortality. American Journal of Physical Anthropology 158:441-451. https://doi.org/10.1002/ ajpa. 22806

Dobson, R. B., editor. 1983. The peasants' revolt of 1381. Second edition. MacMillian, London, UK.

Fath, B. D., C. A. Dean, and H. Katzmair. 2015. Navigating the adaptive cycle: an approach to managing the resilience of social systems. Ecology and Society 20(2):24. https://doi.org/10.5751/ ES-07467-200224

Folke, C. 2006. Resilience: the emergence of a perspective for social-ecological systems analyses. Global Environmental Change 16(3):253-267. http://dx.doi.org/10.1016/j.gloenvcha.2006.04.002

Folke, C., R. Biggs, A. V. Norström, B. Reyers, and J. Rockström. 2016. Social-ecological resilience and biosphere-based sustainability science. Ecology and Society 21(3):41. http://dx.doi.org/10.5751/ es-08748-210341

Friborg, O., O. Hjemdal, J. H. Rosenvinge, and M. Martinussen. 2003. A new rating scale for adult resilience: What are the central protective resources behind healthy adjustment? International Journal of Methods in Psychiatric Research 12(2):65-76. https:// doi.org/10.1002/mpr.143

Geels, F. W. 2010. Ontologies, socio-technical transitions (to sustainability), and the multi-level perspective. Research Policy 39 (4):495-510. https://doi.org/10.1016/j.respol.2010.01.022

Godin, B. 2012. Social innovation: utopias of innovation from $\mathrm{c}$. 1830 to the present. Working Paper No. 11. Project on the Intellectual History of Innovation, Montréal, Québec, Canada.

Gottfried, R. S. 1983. The Black Death: natural and human disaster in Medieval Europe. Free Press, New York, New York, USA.

Gunderson, L. H. 2002. Understanding resilience: theory, metaphors, and frameworks. Pages 3-18 in L. H. Gunderson and L. Pritchard Jr, editors. Resilience and the behavior of large-scale systems. Island, Washington, D.C., USA.

Haddock, D. D., and L. Kiesling. 2002. The Black Death and property rights. Journal of Legal Studies 31:S545-S587. https:// doi.org/10.1086/345566

Hatcher, J. 2009. The Black Death: the intimate story of a village in crisis, 1345-1350. Hatcher, London, UK.

Henneman, J. 1968. The Black Death and royal taxation in France, 1347-1351. Speculum: A Journal of Medieval Studies 43 (3):405-428. https://doi.org/10.2307/2855836

Herlihy, D. 1997. The Black Death and the transformation of the West. Harvard University Press, Cambridge, Massachusetts, USA. 
Hilton, R. 2003. Bondmen made free: Medieval peasant movements and the English rising of 1381. Second edition. Routledge, London, UK. https://doi.org/10.4324/9780203169315

Hirshleifer, J. 1966. Disaster and recovery: the Black Death in Western Europe. Memorandum RM - 4700-TAB. RAND Corporation, Santa Monica, California, USA.

Holling, C. S. 1973. Resilience and stability of ecological systems. Annual Review of Ecology and Systematics 4:1-23. https://doi. org/10.1146/annurev.es.04.110173.000245

Holling, C. S., F. Berkes, F., and C. Folke. 1998. Science, sustainability and resource management. Pages 342-362 in $\mathrm{F}$. Berkes, and C. Folke, editors. Linking social and ecological systems: management practices and social mechanisms for building resilience. Cambridge University Press, Cambridge, UK.

Holling, C. S., and L. Gunderson. 2002. Resilience and adaptive cycles. Pages 3-22 in L. Gunderson and C. S. Holling, editors. Panarchy: understanding transformations in human and natural systems. Island, Washington, D.C., USA.

Intergovernmental Panel on Climate Change (IPCC). 2012. Managing the risks of extreme events and disasters to advance climate change adaptation. A special report of Working Groups I and II of the Intergovernmental Panel on Climate Change. C. B. Field, V. Barros, T. F. Stocker, D. Qin, D. J. Dokken, K. L. Ebi, M. D. Mastrandrea, K. J. Mach, G.-K. Plattner, S. K. Allen, M. Tignor, and P. M. Midgley, editors. Cambridge University Press, Cambridge, UK. [online] URL: https://www.ipcc.ch/site/assets/ uploads/2018/03/SREX Full Report-1.pdf

Jackson, D., A. Firtko, and M. Edenborough. 2007. Personal resilience as a strategy for surviving and thriving in the face of workplace adversity: a literature review. Journal of Advanced Nursing 60(1):1-9. https://doi.org/10.1111/j.1365-2648.2007.04412. $\underline{\mathrm{X}}$

Jedwab, R., N. Johnson, and M. Koyama. 2016. Economic shocks, inter-ethnic complementarities and the persecution of minorities: evidence from the Black Death. Institute for International Economic Policy, George Washington University, Washington, D.C., USA.

Kelly, J. 2005. The great mortality: an intimate history of the Black Death, the most devastating plague of all time. Harper Collins, New York, New York, USA.

Kitsikopoulos, H. 2002. The impact of the Black Death on peasant economy in England, 1350-1500. Journal of Peasant Studies 29(2):71-90. https://doi.org/10.1080/714003952

Langer, L. N. 1975. The Black Death in Russia: its effects upon urban labor. Russian History 2(1):53-67. https://doi. org/10.1163/187633175X00045

McDonald, G., D. Jackson, L. Wilkes, and M. H. Vickers. 2012. A work-based educational intervention to support the development of personal resilience in nurses and midwives. Nurse Education Today 32(4):378-384. https://doi.org/10.1016/j. nedt.2011.04.012

McGowan, K., and F. Westley. 2015. At the root of change: the history of social innovation. Pages 52-68 in A. Nicholls, J. Simon, and M. Gabriel, editors. New frontiers in social innovation research.
Plagrave Macmillan, London, UK. https://doi.org/10.1057/97811375068013

Moore, M.-L., P. Olsson, W. Nilsson, L. Rose, and F. R. Westley. 2018. Navigating emergence and system reflexivity as key transformative capacities: experiences from a global fellowship program. Ecology and Society 23(2):38. https://doi.org/10.5751/ ES-10166-230238

Mumford, M. D. 2002. Social innovation: ten cases from Benjamin Franklin. Creativity Research Journal 14(2):253-266. https://doi.org/10.1207/S15326934CRJ1402 11

Noymer, A. 2007. Contesting the cause and severity of the Black Death: a review essay. Population and Development Review 33 (3):616-627.

Olsson, P., M.-L. Moore, F. R. Westley, and D. D. P. McCarthy. 2017. The concept of the Anthropocene as a game-changer: a new context for social innovation and transformations to sustainability. Ecology and Society 22(2):31. https://doi. org/10.5751/ES-09310-220231

Page, S. 2010. Diversity and complexity. Vol. 2. Princeton University Press, Princeton, New Jersey, USA.

Palmer, R. C. 1993. English law in the age of the Black Death, 1348-1351: a transformation of governance and law. University of North Carolina Press, Chapel Hill, North Carolina, USA.

Pamuk, Ş. 2007. The Black Death and the origins of the 'Great Divergence' across Europe, 1300-1600. European Review of Economic History 11(3):289-317. https://doi.org/10.1017/ $\underline{\mathrm{S} 1361491607002031}$

Platt. C. 1997. King Death: the Black Death and its aftermath in Late Medieval England. Routledge, London, UK. https://doi. org/10.4324/9781315072371

Prigogine, I., and I. Stengers. 1984. Order out of chaos: man's new dialogue with nature. New Science Library, Boulder, Colorado, USA.

Slack, P. 1988. Responses to Plague in early modern Europe: the implications of public health. Social Research 55(3):433-453.

Shrewsbury, J. F. D. 1971. A history of Bubonic Plague in the British Isles. Cambridge University Press, Cambridge, UK.

Silverman, H., and G. M. Hill. 2018. The dynamics of purposeful change: a model. Ecology and Society 23(3):4. https://doi. org/10.5751/ES-10243-230304

Simon, H. A. 1982. Models of bounded rationality: behavioral economics and business organization. Vol. 2. The Massachusetts Institute of Technology Press, Cambridge, Massachusetts, USA.

Sloane, B. 2011. The Black Death in London. The Mill Press, Briscombe Port, Gloucester, UK.

Smith, B. W., J. Dalen, K. Wiggins, E. Tooley, P. Christopher, and J. Bernard. 2008. The brief resilience scale: assessing the ability to bounce back. International Journal of Behavioral Medicine 15 (3):194-200. https://doi.org/10.1080/10705500802222972

Stone-Jovicich, S., B. E. Goldstein, K. Brown, R. Plummer, and P. Olsson. 2018. Expanding the contribution of the social sciences to social-ecological resilience research. Ecology and Society 23 (1):41. https://doi.org/10.5751/ES-10008-230141 
Tuchman, B. W. 1978. A distant mirror: the calamitous 14th century. Alfred A. Knopf, New York, New York, USA.

Tugade, M. M., and B. L. Fredrickson. 2004. Resilient individuals use positive emotions to bounce back from negative emotional experiences. Journal of Personality and Social Psychology 86 (2):320-333. https://doi.org/10.1037/0022-3514.86.2.320

van Zwanenberg, P., A. Cremaschi, M. Obaya, A. Marin, and V. Lowenstein. 2018. Seeking unconventional alliances and bridging innovations in spaces for transformative change: the seed sector and agricultural sustainability in Argentina. Ecology and Society 23(3):11. https://doi.org/10.5751/ES-10033-230311

Walker, B., and F. Westley. 2011. Perspectives on resilience to disasters across sectors and cultures. Ecology and Society 16(2):4. https://doi.org/10.5751/es-04070-160204

Watkins, R. N. 1972. Petrarch and the Black Death: from fear to monuments. Studies in the Renaissance 19:196-223. https://doi. org/10.2307/2857093

Westley, F., and K. McGowan, editors. 2017. The evolution of social innovation: building resilience through transitions. Edward Elgar, Cheltenham, UK.

Wray, S. K. 2009. Communities in crisis: Bologna during the Black Death. The Medieval Mediterranean Series. Brill, Leiden, The Netherlands.

Wray, S. K. 2004. Boccaccio and the doctors: medicine and compassion in the face of plague. Journal of Medieval History 30 (3):301-322. https://doi.org/10.1016/j.jmedhist.2004.06.005

Wood, J. W., R. J. Ferrell and S. N. Dewitte-Avina. 2003. The temporal dynamics of the fourteenth-century Black Death: new evidence from English ecclesiastical records. Human Biology 75 (4):427-448. https://doi.org/10.1353/hub.2003.0067

Yeager, D. S., and C. S. Dweck. 2012. Mindsets that promote resilience: when students believe that personal characteristics can be developed. Educational Psychologist 47(4):302-314. https:// doi.org/10.1080/00461520.2012.722805

Ziegler, P. 1969. The Black Death. Faber \& Faber, London, UK.

Ziegler, P. 1998. The Black Death. Second edition. Faber \& Faber, London, UK. 